\title{
Research on the Rights and Interests of Industrial and Mining Resources in the Grassland Pastoral Areas of Inner Mongolia in the View of the World System Theory
}

\author{
------ Taking Shibao Iron Mine in Inner Mongolia as an Example \\ Wu Xiuqing ${ }^{1}$, Yang Changbao ${ }^{2}$ \\ ${ }^{1}$ Hohhot Minzu College, Hohhot, Inner Mongolia, 010051 \\ ${ }^{2}$ Inner Mongolia University, 010021
}

Keywords: World System Theory, Grassland Pastoral Area in Inner Mongolia, Exploitation of Industrial and Mining Resources, Distribution of Rights and Interests

\begin{abstract}
In the development of industrial and mineral resources in the grassland pastoral areas of Inner Mongolia, the distribution of rights and interests is a crucial problem. Based on this, with the development of sociology in the world system theory as a research perspective, the paper firstly analyzes the connotation of the world system theory; then briefly discusses the current Inner Mongolia grassland mining resources development in the stakeholders, such as local government, industrial and mining enterprises and residents in pastoral areas. Finally, it puts forward some suggestions on how to improve the allocation of equity, such as the construction of ecological compensation mechanism, improving the land requisition compensation standard, improving the social security system construction as well as benefit sharing mechanism.
\end{abstract}

\section{Introduction}

Inner Mongolia, located in North China, is a Northern Frontier Province, with an area of third provinces and regions, with a very rich mineral resources. Since the reform and opening up, the mining development in Inner Mongolia has been highly valued, and the mining industry has been playing a more and more important role in the economic development. Especially since the implementation of western development strategy, the economic development of Inner Mongolia GDP a thousand li a day, the average annual growth rate is far higher than the national average growth rate, the growth rate ranked first in the country for many years. The result is the rising proportion of Inner Mongolia's economy in the whole country. The per capita GDP is even more than the first strong province of China's economy, ranking the seventh in all provinces and autonomous regions of China. But in the development of Inner Mongolia mining industry is also facing many problems, in addition to environmental and ecological problems as everyone knows, there is equity allocation problem, the allocation of rights and interests between the various stakeholders is uneven, especially mine herdsmen equity allocation is the main manifestation of the problem of low form. Based on this, the article analyzes the rights and interests of the exploitation of the industrial and mining resources in the pastoral areas of Inner Mongolia by the view of the world system theory.

\section{Research Object}

The survey point is Shibao iron mine that located in Huhe point Xilamuren Town Village of Baotou Darhan Muminggan Joint Banner in Inner Mongolia. The iron mine collection the grassland of Huhe point Xilamuren Town Village in 1988, which is the flag of the second industrial and mining enterprises. The research object is the main body involved in the development of Shibao iron ore in the three party including herdsman of Huhe point Xilamuren Town Village, Shibao iron mine and Damao County Government.

In 2002 the industrial vertical flag and banner three to promote the development of 
industrialization and development strategy, planning its local economic development thinking. Under the guidance of such policy, the development of industrial and mining resources has been paid more attention.

\section{Theoretical Perspective ----- the Theory of World System}

As an important school in the theory of social development, world system theory has a wide range of influence and numerous fans around the world. The origin of the world system theory in the United States is a theory of social development, the famous historian and sociologist Emanuel Wallerstein proposed in 1970s, which is to further deepen and the development of attachment theory. Different from the previous research on social development, the development of different civilizations and different regions is regarded as individual. The theory of the world system focuses more on the development and change of the world and its components from the perspective of system, and takes the world system as the object to explore its development trend and law. In Wallerstein's view, the world system can be divided into three levels: the first level is the National Center, the comprehensive national strength of their strongest, highest level of production, but also has economic foundation and perfection of the top scientific research strength; the second level is the half edge layer, their comprehensive national strength is weaker than the center of the state, but also a relative strong production capacity and comprehensive national strength; the third level is the edge layer, their national strength and the lowest level of the weakest production technology. The theoretical system of this kind of division and our original worlds are very similar. As a rigorous theoretical system, the theory of world system applies not only to the analysis and definition of the relationship between countries but also to the internal structure of a country in many areas such as sociology, management and economics. In this study, the theory of world system is also applied. As the so called application, it refers to the application of the method level, that is, from the perspective of center, half edge and edge, we can analyze the stakeholders in the development of Inner Mongolia's Grassland and pastoral areas.

\section{Research on the Interest Subject in the Development of the Grassland and Pastoral Areas in Inner Mongolia}

\subsection{Local government}

Among the main interests of the development of industrial and mining resources in the pastoral areas of Inner Mongolia, the local government is in the most core position. From the perspective of world system theory, local governments occupy the center of all stakeholders. It is not only the most important interest body, but also a dependent force to coordinate other stakeholders' relations, playing a crucial role. There are many forms of interest in the development of industrial and mining resources by local governments. First of all, from the direct income, the local government land transfer to the enterprise for the development of mineral resources, will receive a huge amount of land premium, which is composed of the local government budget revenue head; secondly, from the indirect income, the development of mineral resources is equivalent to the production by the industry to replace the agricultural and animal husbandry production, can to promote local economic development, so as to increase government revenue, according to statistics, in the process of land acquisition, government revenue by 52\%;

\subsection{Industrial and mining enterprises}

Inner Mongolia's pastoral area is concentrated in industrial and mining resources, and the mining of industrial and mineral resources is inseparable from the participation of industrial and mining enterprises. In other words, industrial and mining enterprises are the backbone of promoting the economic development of pastoral areas. At the same time, industrial and mining enterprises are also one of the stakeholders in the exploitation of mineral resources in the pastoral areas. They enjoy the huge economic benefits brought by mining resources on the one hand, and grab huge profits. On the other hand, they have to shoulder multiple social responsibilities. For example, in 
order to obtain land from herdsmen, industrial and mining enterprises must give enough compensation, and cooperate with the government to establish a long-term mechanism to avoid social problems arising from exploitation and exploitation of industrial and mineral resources. Not only that, the industrial and mining resources will inevitably produce a lot of pollution in the exploitation and exploitation, and the industrial and mining enterprises also need to do a good job of environmental regulation.

\subsection{Pastoral residents}

The population of the pastoral area is an important force for the development of the interests of the industrial and mining resources in the pastoral areas of Inner Mongolia, and is also the most effective group in the distribution of rights and interests. Their identity has dual attributes, on the one hand, as they have in the pastoral area residents, grazing, cultivation, development of mineral resources is a kind of inherent impact on their way of life, forcing them to give up the way of life, instead of using the other way of life; on the other hand, the development of mining resources not only for they compensate a large sum of money, and most of the time can give them to create new employment opportunities. But in general, the income share of the farmers in the land acquisition is not high. The interest groups of farmers only get less than $1 / 3$ of the land expropriation income, which is less than $1 / 10$ in the hands of farmers.

\section{Research on Improving the Rights and Interests Distribution in the Development of the Grassland and Pastoral Areas in Inner Mongolia}

\subsection{Construction of ecological compensation mechanism}

As a frontier province in the northern part of China, Inner Mongolia has a vast territory and a dense resource. There are many different types of industrial and mineral resources. There are many mining cities, which have made important contributions to the economic development and urbanization process of Inner Mongolia. But note that the development and exploitation of mining resources. Although the Inner Mongolia region's economic development has played a very important role, but also brought a lot of problems, especially the ecological environment and the level of local farming livelihood problems, due to various pollution mining caused pollution and land desertification in Inner Mongolia very serious. The emergence of these problems has a great relationship with the imperfection of the ecological compensation mechanism. As the largest beneficiary of the development of industrial and mineral resources, the government has both obligations and responsibilities to do well in the construction of Inner Mongolia's ecological compensation mechanism, so that the development of industrial and mineral resources will not become a killer of environmental destruction. The main goal of the ecological compensation mechanism is to compensate for the destruction of the natural ecosystem of the mining area, and to minimize the main means and important ways to reduce the industrial and mineral resources pollution to the mining area as much as possible. Aiming at the ecological compensation mechanism in the source of funds, the implementation of defects, performance appraisal, local governments need to strengthen the mechanism construction, make the distribution rights and responsibility to implement the combination of mineral resources development, reduce the phenomenon of separation of powers and responsibilities.

\subsection{Improving the standard of compensation for expropriation}

In the local government, industrial and mining enterprises and pastoral areas, the residents in pastoral area are the largest but least allocated groups, which are not only different from the basic requirements of social equity, but also not conducive to the long-term development of industrial and mining enterprises. Therefore, in the exploitation of industrial and mining resources in pastoral areas, we must improve the standard of expropriation compensation, and compensate for the losses suffered by the residents in the pastoral area due to the development of industrial and mineral resources. Taking Shibao iron ore as an example, we need to deal with the following two tasks. First 
of all, the scope of compensation should be expanded. To adhere to the original scope of compensation, such as the foundation of the right to the contracted management of land compensation, attachment compensation and so on, living resettlement, employment and housing subsidies for children at the same time into the scope of compensation. At the same time, local governments still need to set up a special fund for landless farmers and herdsmen in pastoral areas of employment, to avoid mining resources development and the homeless. Secondly, we should improve the amount of compensation. In the previous development of industrial and mineral resources, the rights and interests distribution of residents in pastoral areas is actually lower than that they pay. Many times the amount of compensation is not enough to satisfy the original level of land lost farmers in life, education, medical treatment and so on. Therefore, in compensation, we must strictly operate according to market mechanism, and include professional resettlement fees, endowment insurance fees and medical insurance premiums into the compensation costs, so as to raise the total amount of compensation.

\subsection{Improving the social security system}

With the increasing standardization of mining resources in grassland and pastoral areas of Inner Mongolia, the government's compensation for landless farmers is also increasing. However, influenced by various factors, many landless farmers and herdsmen can't make good use of the government's compensation. After the compensation money arrives, it is not blindly used for investment that is consumed in other unnecessary links, ranging from a few years to more than ten years. The land lost farmers and herdsmen lost their dependence on life, which is completely contrary to the original idea of the government and is not conducive to the construction of a socialist harmonious society. Therefore, in the development of industrial and mineral resources, it is necessary to improve the social security system as a solid backing. Taking Shibao iron mine as an example, faced with the loss of labor opportunities due to land lost, the government needs to strengthen financial transfer payment and set up corresponding employment placement fund, which is specially used for re-employment of landless farmers. At the same time, Shibao iron mine should also actively create employment opportunities for landless farmers, so that the land lost farmers will not be unemployed. At present, in the social security system is not perfect, the local government should try to landless farmers and herdsmen into urban endowment insurance category, and to guide the use of reasonable compensation for farmers and herdsmen, strengthen anti-fraud education, especially to strengthen the anti MLM education, reduce the risk of landless farmers and herdsmen living as much as possible, so that the allocation of equity is more perfect and reasonable.

\subsection{Construction of benefit sharing mechanism}

At present, the mechanism of rights and interests distribution in the development of industrial and mineral resources in pastoral areas is actually relatively simple. Many times, the so-called rights and interests distribution is close to the nature of buyout. The government gave land lost farmers and herdsmen with a certain amount of compensation, and the land farmers and herdsmen completely lost the right to contract the management of the grassland. Such a situation is quite risky for the land lost farmers and herdsmen with low cultural level and poor living skills, especially the huge amount of compensation given to the herdsmen at once, which can easily lead to various social adverse events. In this regard, as the main beneficiaries of the distribution of the interests of the government and between government and farmers and herdsmen business needs from the new mining resources development model considering pastoral areas; constructing the corresponding benefit sharing mechanisms, the development of mineral resources to pastoral areas did not become "a hammer" sale. The local government needs to strengthen the design from the system to ensure the protection of the legitimate rights and interests of the farmers and herdsmen. There are many ways to solve the problem of land use in the development of industrial and mineral resources, such as construction land, mining land and public welfare land, and different land uses can adopt different ways of compensation. Taking public welfare land as an example, a part of the income of land assets can be used as the social security fund for the land lost farmers and herdsmen. In addition, land expropriation in the mining industry, can also implement land ownership system, the 
farmers every year to receive dividends from the land, avoid eating situation.

\section{Conclusions}

The development of industrial and mineral resources involves multiple stakeholders. How to balance the rights and interests between different stakeholders is one of the important factors that affect the development of industrial and mineral resources. From the perspective of the theory of world system, all the interests of the industrial and mining development show a clear center - half edge - edge situation. In the marginal situation, the people in the pastoral areas pay the most and the distribution of the rights and interests is the least, which is obviously not conducive to the sustainable development of the industrial and mining industry. In this regard, the government and industrial and mining enterprises need to do a good job of balancing the rights and interests from the perspective of unity of power and responsibility.

\section{Acknowledgements}

This paper is grateful for the support of the PhD project of the Scientific Research Project of Hohhot National Academy of Nationalities

\section{References}

[1] Gao T M, Zhang R Q. Influence of Reclamation on Grassland Slope in Farming-Pastoral Areas, Inner Mongolia[J]. Advanced Materials Research, 2013, 726-731:3743-3746.

[2] Sa C, Liu G, Wang M, et al. Study on hazard factor assessment caused by snow disaster in pastoral areas of Inner Mongolia grassland based on Multi-Source Remote Sensing Data[C]// Meeting of Risk Analysis Council of China Association for Disaster Prevention. 2016.

[3] Liu M, Dries L, Heijman W, et al. The Impact of Ecological Construction Programs on Grassland Conservation in Inner Mongolia, China[J]. Land Degradation \& Development, 2017.

[4] N.B. Minority Education in a Pastoral Area of Inner Mongolia Autonomous Region: A View on the School Choice of Mongolian Minority Students[J]., 2012:105-116.

[5] Zhang X R. Study on the Solar Energy Heat Pump Space Heating System in the Agricultural and Pastoral Areas in Inner Mongolia[M]// Energy Solutions to Combat Global Warming. Springer International Publishing, 2017.

[6] Gao T M, Zhang R Q. Degradation Mechanism and Applicability of Irrigation Recovery Technique on Xilamuren Grassland, Inner Mongolia[J]. Advanced Materials Research, 2012, 518-523:5016-5019.

[7] Huriletemuer, Hurile L, Zhang C, et al. An epidemiological study of stroke and its sub-types in the over 55 Mongolian and Han populations in a pastoral area of inner Mongolia. [J]. International Journal of Stroke, 2011, 6(5):468.

[8] Jiao Y, Hou J H, Zhao J H, et al. Land-use change from grassland to cropland affects $\mathrm{CH} 4$ uptake in the farming-pastoral ecotone of Inner Mongolia[J]. Zhongguo Huanjing Kexue/china Environmental Science, 2014, 34(6):1514-1522.

[9] Conte T J, Tilt B. The Effects of China’s Grassland Contract Policy on Pastoralists' Attitudes towards Cooperation in an Inner Mongolian Banner[J]. Human Ecology, 2014, 42(6):837-846. 